\title{
Waste Management Model-Based Design Character in Junior High School as a Tool of the Economic Empowerment
}

\author{
Lita Dwipasari \\ Fak. Ekonomi, Universitas Merdeka Malang, Indonesia
}

\begin{abstract}
School is a strategic place to instill a new culture for the younger generation. Clean culture, culture of environmental care and caring culture of the nation can be implanted through school learning. Waste management is an activity that will make the students (young people) have such a culture of learning and mutual assistance in improving the social economy. Therefore, this research aims to create a model of waste management for the first Secondary School. This model is taken from the school who have successfully performed management activities (based on reports from Bank Trash). In Malang, there is only one high school is doing, while others schools have many difficulties in the field. The resulting model will be implemented and tested at the troubled school. And the results will be measured qualitatively and quantitatively. Qualitative analysis of physical changes visible in the school, school and community behavior change and increase economic growth to the relevant parties. While the quantitative analysis performed by Wilcoxon statistical tests with SPSS.
\end{abstract}

Keywords: Management waste, Junior high school, Economic empowerment

\subsection{Background Of The Problem}

\section{Introduction}

Indonesia is a vast country consisting of 17,500 islands with a population of 251160124 people whose presence in the islands scattered in various towns and villages. In this context, the activities of waste management is not easy. Management of waste management requires creativity in accordance with the conditions of each area. If observed, the waste management sector in Indonesia as a microcosm of the world waste, where waste management issues in various regions in Indonesia have in common numerous challenges that must be faced in many countries.

Through Law No. 18 of 2008 regarding waste management and Goverment Regulation No. 81 In 2012, the Indonesian government emphasizes waste management with a new paradigm, namely the principle of $3 \mathrm{R}$ (Reduce, Refuse, Reuse) with the collaboration of goverment, business entities, private and SME. And for more "grounding" the garbage Bank rules were developed which have the task to change the way people's garbage, educate and familiarize the public sort, choose and appreciate up to the development of social economy. Bank will buy inorganic waste (paper, plastic, cans) to then be recycled into raw materials needed factory.

Garbage bank in Indonesia through in Februari 2012 totaled 471 units and increased to 886 units in May 2012. The form of the waste bank contribution is increased employment (job creation) and an increase in community income in the form of additional income in the form of bank savings waste (Garbage Bank Indonesia Profile, 2012). In carrying out their duties in the trash Bank Indonesia has some of auxiliaries such as auxiliaries of the community, the group built office/industrial and auxiliary school.

Malang is one of the cities in the province of East Java in Indonesia. Bank of garbage in the city of Malang is one of the pilot waste banks in Indonesia. The garbage bank named BSM (Garbage Bank Malang). Auxiliaries of community development is progressing very rapidly, but unlike the case with the target group of schools has decreased because of the many obstacles faced by the school in its waste management activities. In 2011 recorded 136 auxiliaries of school, in 2012 to 99 schools (there are 22 Kindergarten school, 95 Elementary school and 4 junior high school and 1 senior high school ), in 2013 dropped to 25 schools, comprising 3 kindergarten school, 19 Elementary school, 2 junior high school and 1 senior high school. On the others, every year in the city of Malang waste increased $10 \%$ from 400 tons per day in line with the increase the population.

Only Garbage Bank in Malang waste that has built a school group. To overcome the obstacles faced by the target group in the school garbage banks will require instructions on overcoming constraints experienced. To generate instructions or a good model, this study targeted at Junior High School group. So that this model can be used by other Garbage Bank in Indonesia. This model will be a clue as to how waste management activities conducted in junior high school.

Based on data from Malang City Department of Education (December 2013) there were 90 junior high schools in Malang with the total number of students as much as 33245 students. If schools implement waste management activities, it is remarkable how much for the environment. This happens because the awareness of 
the waste has been embedded and trained 33245 students through their schools early on. School environment will be cleaner, healthier and asri. If cultural awareness it becomes a habit then it will be the acceleration of become populist economic drivers in Indonesia in addition to the emergence of "conscious rubbish"

\subsection{Research Objectives}

The purpose of this research is:

1) Create a model of waste management within the junior high school

2) Test the model of waste management within the junior high school

\subsection{Benefits of Research}

1) Models created can be used as a technical guide on the implementation of the waste management activities of junior high school because the model has been tested.

2) Conduct a school group that turned against the trash can happen, of behavior "forced" to collect / dispose of waste in place and the behavior of "normal" to the trash because it was not "aware" usefulness becomes "aware of the trash" because of its economic value.

\section{Theory Study}

The concept of waste management and traditionally in Indonesia has begun to be abandoned by several major cities in Indonesia. For example, the population of the city of Ubud Bali, which has started to process the waste into biogas as energy for cooking and lighting houses. Then Hamlet Badegan Society, Bantul, Yogyakarta which has been set up Garbage Bank "Gemah Ripah" as a place to change their domestic waste into money (Kompas, 2008). Garbage Bank is also helpful to reduce the volume of domestic waste that is disposed of TPS. From these examples show that people at lower levels (households) of several cities in Indonesia have started to be directly involved in implementing the concept of modern waste management,namely the concept of $3 \mathrm{R}$ (Reduse, Reuse and Recycle).

\subsection{Garbage Bank}

Statistics developments Garbage Bank in Indonesia in February 2012 is 471 pieces with as many as 47 125 the number of savers while the amount of waste that is managed is $755600 \mathrm{~kg} /$ month with a turnover value of Rp. 1.64832 billion per month. This statistic increases to 886 pieces Garbage Bank goes according to the data in May 2012, the number of depositors as much as 84623 people and the amount of waste that is managed by 2,001,788 kg per month and make money of Rp. 3.182281 billion per month. Bank of garbage that this area was established government, responsible for assisting the city government to reduce the volume of waste and provide public awareness about sorting, managing waste and making it an economically valuable goods in order to provide additional income. While garbage Bank established in Malang with cooperative legal entity on July 26, 2011 has helped manage the dry waste generated poor citizens. In its operations, the system use to recruit Malang waste bank and transact with the auxiliaries of the school looks as follows:

a) For the formation of the unit auxiliaries of BSM to school is 40 students / teacher / employee

b) Formation of BSM unit should form a committee consisting of the chairman, secretary and treasurer

c) Board BSM unit members will weigh the garbage that has been defined and disaggregated according to mecatat passbook and ledger board members

d) Garbage is collected by the unit will be taken by the officer BSM

e) Officers will weigh garbage BSM BSM unit and recorded in the passbook group and gave a memorandum of weighing results

f) Copy of the memorandum scaled by officers will be handed over to the officer BSM BSM Teller and reconsideration based on the result of the note.

g) BSM is a type of savings in regular savings, saving the school, saving the environment and social savings

h) Prices are set by BSM and waste consisting of 2 members of the unit price of the BSM and BSM price alone (table 3 in the appendix)

i) Board would appreciate garbage BSM unit members with member prices, and written in book member savings

j) To waste collected in the BSM unit will be appreciated by the unit price of BSM and BSM with written in book account BSM unit, where the difference in price is intended to motivate managers BSM units provide services to their members.

\section{2 . Character Education}

In order to further strengthen the implementation of character education in schools in Indonesia, it has identified 18 schools value that should be developed, in which the character is rooted in religion, Pancasila, Culture. 18 values are: (1) Religious, (2) Be honest, (3) Tolerance, (4) Discipline, (5) hard work, (6) Creative (7) 
Independent, (8) Democratic, (9) Pain want to Know, (10) The spirit of Nationality, (11) Love the country, (12) Rewarding Achievement, (13) Friendly/Communicative, (14) Love Peace, (15) Joy of Reading, (16) Environmental Care, (17) Social Care, (18) Responsibility (Pusat Kurikulum,Pengembangan dan Pendidikan Budaya dan Karakter Bangsa:Pedoman Sekolah, 2011). In the implementation of 18 values forming the character of the nation in its development priorities and conditions depart from the interests of their respective schools. This should be selected and assigned based on the analysis of the context, so that its implementation is possible there is a difference in the type of character values that developed between the school and the one or the other. Implementation of character values that will be developed can be started from the values of essential, simple, and easy to implement, such as: clean, neat, comfortable, disciplined, polite and courteous. The implementation of the character education needs to involve the entire school community, parents and the surrounding community ((Pusat Kurikulum,Pengembangan dan Pendidikan Budaya dan Karakter Bangsa:Pedoman Sekolah, 2011).

The concept of school waste management is an activity that can foster the values of national character that is planting hygiene, discipline, mutual cooperation, environmental care and social care. Of toxicity students who throw garbage at will and forced to dispose of waste (for fear of the teacher / sanctions) become aware of the garbage. Consciously aware if garbage bins that will be able to bring disasters such as floods and disease. Conscious waste also means that the waste will be able to have a good economic value for the people who create on as well as for other community groups.

\subsection{Method of Data Collection}

\section{Research}

\section{Activity 1. Design of waste management models for junior high school students.}

This research is grounded reseach because the theory is built on existing data (Nazir, 2014). This research is to gather information and find a picture of the phenomena that occur at school about their activities in the school waste management, analysis of the data used to build the model is based on the analysis of the IPO (Input Process Output).

Techniques of data collection is done by census method in which all respondents in the population used. The technique used in this study are:

a. The first questionnaire (Questionnaire for building models)

b. Interview. It is depth interview process to ask jawabsecara depth information obtained in accordance with the purpose of research. Interviews were conducted to gather information about the opinions and experiences of respondents mengesplorasi.

c. Focus group discussions is to reveal and accept the norms and issues of concern to the group

d. Brainstorming

e. Monitoring

Activity 2 Test models of school waste management

The data collection techniques with :

a. The second questionnaire (pretest). The second questionnaire was constructed based on the design of waste management model that has been made.

b. Implementation of the model (socialization and guidance)

c. Monitoring. Monitoring in this case is not just to see what happens in schools but also provide the necessary treatment and then see the results.

d. Post test. Post a Field tests conducted testing (field tests) using a third questionnaire

e. From the results of tests conducted test models. The tests were conducted with statistical inference: hypothesis testing sample paired Wilcoxon (non-parametric).

\subsection{Analysis of Data}

Research of the design using the one-group pretest-posttest as described below:

One group-posttest Design

$\begin{array}{cccr}\text { Group } & \text { Pretest } & \text { Treatment } & \text { Postest } \\ \text { A } & \text { O1 } & \text { X } & \text { O2 }\end{array}$

eksperiment design

Remarks: Experimental Group A.

$\mathrm{O} 1=$ Test beginning (pretest) 


$$
\begin{aligned}
\mathrm{O} 2 & =\text { Test end (posttest) } \\
\mathrm{X} & =\text { Model waste management }
\end{aligned}
$$

Instrument used each test phase models are:

1) Setting a target school (respondent)

2) Identify the initial data of the respondents ie existing material checklist

3) Socialization models

4) Implementation of experimentation and preparation of instrument observations

5) Observation (observation) on the performance of the experiment will be carried out periodically according to the schedule that has been set. Record book immediately enter data with the primary data.

6) Analysis and interpretation of experimental results

At this stage the data obtained by quantitative and qualitative. The qualitative data obtained from the test action in the form of an increase in the number of accounts and change behavior BSM While quantitative data obtained from the action on test scores pretest and posttest in the experimental group.

The data obtained were analyzed by using a statistical test is the test analysis of two dependent samples (paired) using SPSS.

With the formulation of the problem as follows:

1. Does the design of waste management models are made can provide tangible results for Junior High school

The formulation of the hypothesis is:

2 . There is/no difference changes with the school environment before and after applying the waste management model design junior

Formula hypothesis:

Test two Ho: $\mu 1=\mu 2$

$\mathrm{H} 1: \mu 1 \neq \mu 2$

Test the Right $\quad \mathrm{Ho}=\mu 1 \leq \mu 2$

$\mathrm{H} 1=\mu 1>\mu 2$

Test the left Ho: $\mu 1 \geq \mu 2$

$$
\mathrm{H} 1=\mu 1<\mu
$$

Decision rule: Method 1: reject $\mathrm{HO}$ if sig ((2-tailed) $<\alpha$ (in this case usually used value $\alpha 1 \%, 5 \%$ or $10 \%$.

Testing a model of success is also seen in the changes in the school environment (more clean and beautiful) and increase school account in BSM

\subsection{Operational Definition of Variables}

- School waste management model is the first model to be built to help the waste management activities of a special school for junior high school. So that this model can be used universally for waste banks in Indonesia for the type of guided group Junior High School. The model is built based on the analysis of an IPO with the following indicators:

Tabel 1. Indikator Penelitian

\begin{tabular}{|l|l|}
\hline \multicolumn{1}{|c|}{ INDICATOR } & \multicolumn{1}{|c|}{ ITEM } \\
\hline Input & Availability of school facilities \\
\hline & The availability of sanitary facilities \\
\hline & Optimizing performance through the field coordinator \\
\hline Process & Empowerment of the school community (teachers, students, employees, janitors / parks) \\
\hline & The division of labor in Teamwork \\
\hline & The involvement of the school community (parents, merchants around the school) \\
\hline Output & The form of accountability for the success of the program \\
\hline & Utilization of the results of activities \\
\hline
\end{tabular}

- $\quad$ Character education: are the values that have been developed in schools as stipulated in the learning activities such as mutual aid, social and environmental awareness, discipline and cleanliness.

- $\quad$ Economic Empowerment democracy is the existence of economically revenue from waste management activities for the school community (cleaning) as well as for the surrounding community.

\subsection{Description of Respondents}

\section{Results And Discussion}

Respondents forming models were respondents who had been successful in implementing its waste management activities reported Garbage Bank Malang. So that the respondents in this study is SMP 10 in the 
city of Malang. Indonesia. Respondents testing the model in this study is a junior enrolled in the BSM but not active since the start in 2012 of the SMP 15, SMP 7, SMP Bahrul Maghfiruh.

Table 2. Description of Respondens

\begin{tabular}{|c|c|c|c|c|}
\hline INFORMATION & $\begin{array}{l}\text { Active Junior } \\
\text { High School } \\
\text { (SMPN 10) }\end{array}$ & $\begin{array}{c}\text { Not active } \\
\text { Junior High } \\
\text { School (SMPN } \\
\text { 15). }\end{array}$ & $\begin{array}{c}\text { Not active } \\
\text { Junior High } \\
\text { School } \\
\text { (SMPN 7) }\end{array}$ & $\begin{array}{c}\text { Not active } \\
\text { Junior High } \\
\text { School (Bahrul } \\
\text { Maghfiruh) }\end{array}$ \\
\hline \multicolumn{5}{|l|}{ INDICATOR : INPUT } \\
\hline Library & yes & yes & yes & yes \\
\hline Parks & yes & yes & yes & yes \\
\hline Canteen & yes & yes & no & no \\
\hline Temporary waste storage & yes & $\begin{array}{l}\text { yes but less } \\
\text { qualified }\end{array}$ & no & $\begin{array}{l}\text { yes but less } \\
\text { qualified }\end{array}$ \\
\hline Separete bins & yes & yes & no & no \\
\hline Garden & yes & yes & $\begin{array}{l}\text { yes, but not } \\
\text { optimal }\end{array}$ & yes \\
\hline Field coordinator & yes & yes & no & yes \\
\hline \multicolumn{5}{|l|}{ INDICATOR: PROCESS } \\
\hline Empowerment of training with BSM & yes & yes & yes & yes \\
\hline Empowerment of training with the other party & yes & no & no & no \\
\hline Empowerment with the direction of the BSM & yes & yes & no & no \\
\hline Empowerment with the direction of the other party & yes & yes & no & yes \\
\hline The duties and responsibilities as chairman & yes & yes & no & yes \\
\hline The duties and responsibilities as executor & yes & yes & no & yes \\
\hline The duties and responsibilities as a supervisor & yes & yes & no & yes \\
\hline Clarity waste management procedures & yes & yes & no & yes \\
\hline Clarity of assignment & yes & yes & no & yes \\
\hline There is no responsibility Clarity & yes & yes & no & yes \\
\hline The involvement of parents & yes & yes & $\begin{array}{l}\text { yes ,but not } \\
\text { optimal }\end{array}$ & no \\
\hline Involment trader around & yes & yes & no & no \\
\hline Accountability & yes & no & no & no \\
\hline \multicolumn{5}{|l|}{ INDICATOR : OUTPUT } \\
\hline Use of results by students & yes & yes & no & no \\
\hline Use of results by school & yes & yes & no & no \\
\hline Use of results by other & yes & no & no & no \\
\hline $\begin{array}{l}\text { Performance achieved in environmental management } \\
\text { activities (adiwiyata) or waste management }\end{array}$ & yes & adiwiyata & not yet & not yet \\
\hline
\end{tabular}

Schools that succeed in the waste management activities are creative schools continue to perform its waste management activities and cooperative efforts with other parties. In general, all schools have a garden and orchard. But not all of the land to optimize learning, including to make compost from the waste they generate. Separate the trash has been owned by the average school but a waste storage (sufficient) is not shared by all schools inactive. This is a major obstacle for transport garbage in garbage hauling BSM can not school every day. If the waste is not managed even to school eyesore. The absence of waste management procedures following the work of officers becomes a problem in itself. Because waste management activities need teamwork to the division of tasks and responsibilities are clear. Not all schools wishing to obtain awards adiwiyata, but school will be easier to implement adiwiyata school waste management. Adiwiyata is an award given by the government on school assessed environment (caring and cultured environment).

2. Models for Junior high school waste management (empirical models)

Waste management model that made analyzed based analysis techniques IPO (input, process and output). This model is obtained from quetioner and interviews with the principal and the field staff for waste management in junior high school. Of indicator Input, Process, Output produces several subsystems in the model. Empirical models of waste management of the school is formed as follows: 
Empirical models: Model Secondary School Waste Management

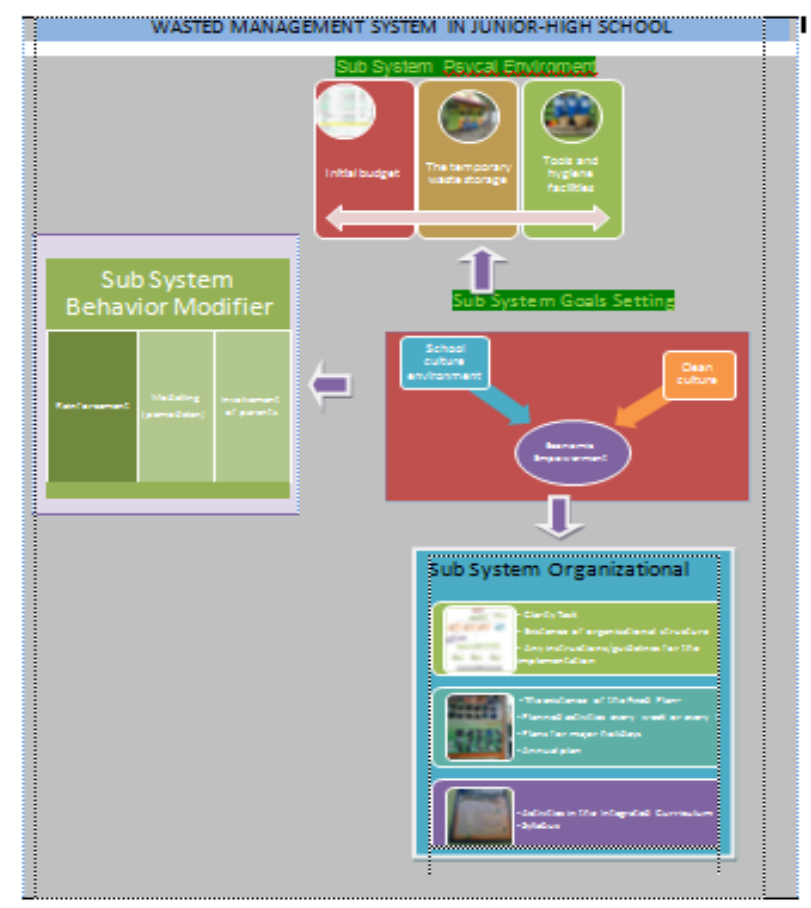

Figure 4. Junior High School Waste Management Model

\subsection{Test Model}

Test models done in 2 ways of test statistics, and descriptions of the observations of researchers. Test statistic for the model is done with phase 1) examination of the results of the questionnaire data normality before and after the briefing/socialization model 2) using non-parametric statistical test and selected paired two-sample test to test the hypothesis.Description of measured results of the changes that occur in the field by using notes and observations of researchers, both physical changes and school reports about the amount of waste bank accounts related parties, such as school accounts, school cleaners and account information of citizens (scavengers) that utilizes the results.

\subsubsection{Test Statistics to Model}

\section{(1) Normality of data $\mathrm{O} 1$ (pretest)}

Results of normality test of data O1 (pretest) using the Shapiro-Wilk test statistic.

By looking at the figures obtained on column probability asymp. SIG is 0.052 which means $>0.05$ (Table 5).

Meanwhile, if seen from the plot (graph) see that:

- In Normal QQ PLOT pretest graphs, the data spread somewhat away from a straight line, although the data follow the path to the upper right (chart 5).

- In the graph Detrended Normal QQ Plot Pretest the data form a specific pattern, it can be said the data distribution is not normal (chart 6).

so that the decision could be made that the data are not normally distributed.

Table 4 Case Proccesing summary

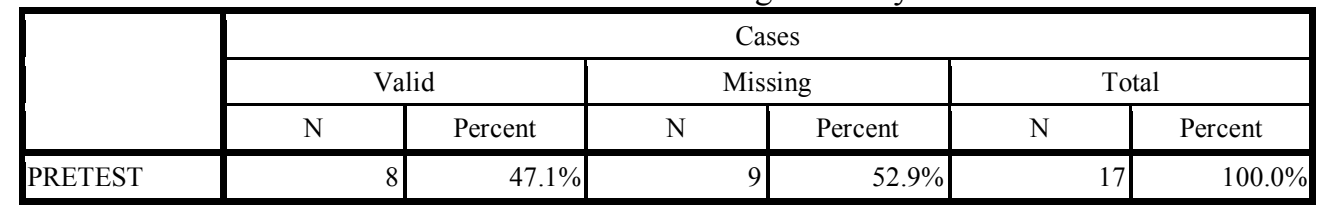

Table 5 Test of Normally

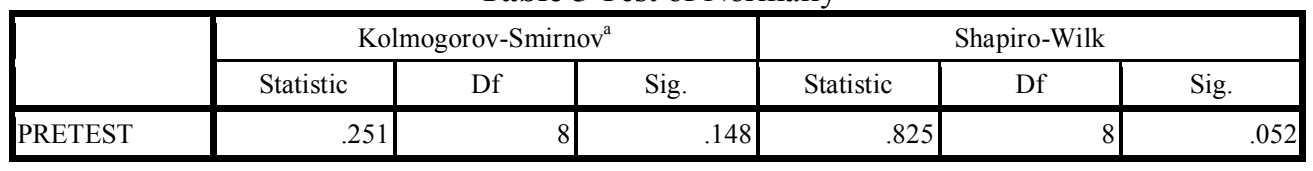




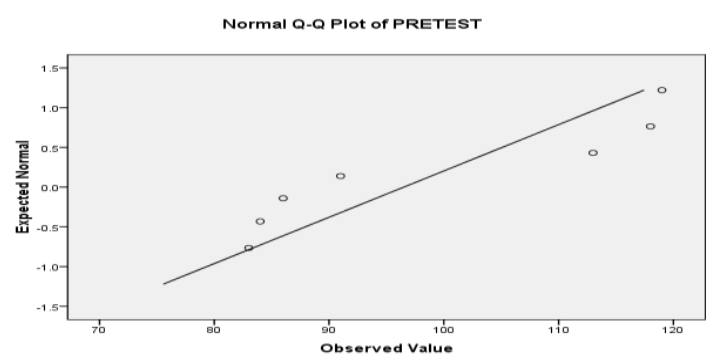

Gambar 5. Normal Q-Q plot Pretest

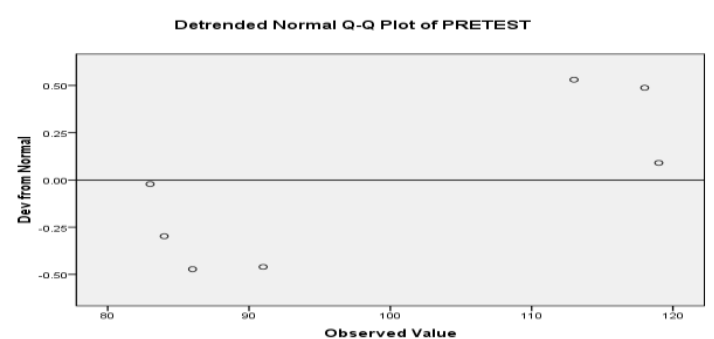

Gambar 6. Detrended Q-Q Plot Pretest

\section{(2) Data normality test (posttest) $\mathrm{O} 2$}

Based on the figures in the column asymp probability. SIG is 0.008 which is $<0.05$ ((Table 7), then Ho is rejected or posttest data distribution does not follow a normal distribution (as basic requirements are probabilitas $>0.05$, then $\mathrm{Ho}$ is accepted, if probability $<0.05$ then $\mathrm{H} 0$ is rejected). If seen from the plot the graph shows that:

- In Normal QQ PLOT graphs posttest, follow the flow of data from the lower left to the upper right (figure 7)

- In the graph Detrended Normal QQ PLOT postest the data form a specific pattern, so it can not be said to be a normal distribution of data (figure 8)

Table 6 Case Procesing Summary

\begin{tabular}{|c|c|c|c|c|c|c|}
\hline & \multicolumn{6}{|c|}{ Cases } \\
\hline & \multicolumn{2}{|c|}{ Valid } & \multicolumn{2}{|c|}{ Missing } & \multicolumn{2}{|c|}{ Total } \\
\hline & $\mathrm{N}$ & Percent & $\mathrm{N}$ & Percent & $\mathrm{N}$ & Percent \\
\hline POSTEST & 8 & $47.1 \%$ & 9 & $52.9 \%$ & 17 & $100.0 \%$ \\
\hline
\end{tabular}

Table 7. Test of Normality

\begin{tabular}{|c|c|c|c|c|c|c|}
\hline & \multicolumn{3}{|c|}{ Kolmogorov-Smirnov ${ }^{\mathrm{a}}$} & \multicolumn{3}{|c|}{ Shapiro-Wilk } \\
\hline & Statistic & Df & Sig. & Statistic & $\mathrm{df}$ & Sig. \\
\hline POSTEST & .311 & 8 & .022 & .749 & 8 & .008 \\
\hline
\end{tabular}

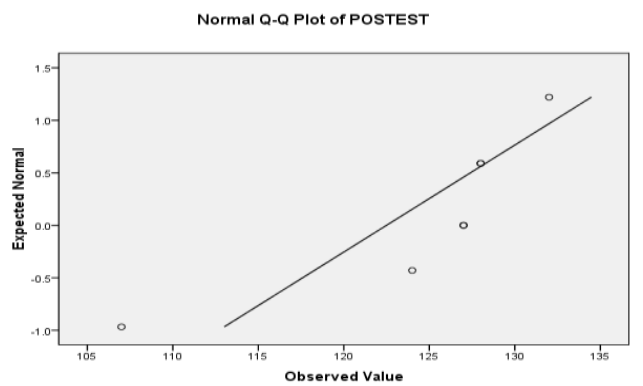

Figure7. Normal QQ plot of posttest

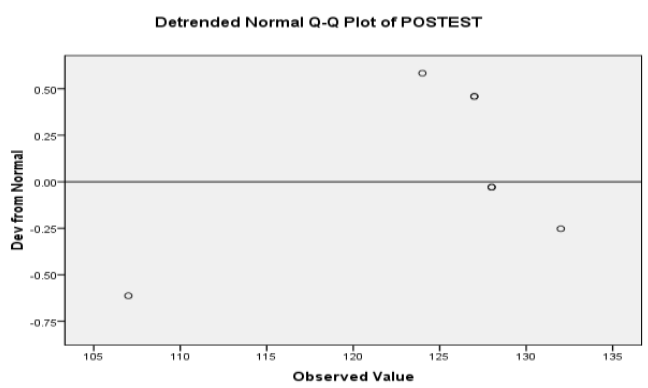

Figure 8. Detrended QQ Plots posttest

\section{(3) Test Paired Two Sample}

Wilcoxon two-sample test dependent

(a) The process of decision-making:

hypothesis: Ho: $\mathrm{d}=0$ or the application of the waste management before and sesuadah direction makes no difference

direction.

Ha: $d \neq 0$ or the application of the waste management before and after the markedly different

\section{(b) Basis of decision-making;}

By looking at the numbers probability, provided that:

probability $>0.05$ then Ho is received and if the probability of $<0.05$ then Ho is rejected

\section{(c) Decision}

By looking at the EXACT probability. SIG is 0.012 (table 8), which means below 0.05, then Ho is rejected. This means that the model is effective for improvement of waste management activities in junior high school. 


\begin{tabular}{|c|c|c|c|c|}
\hline & & $\mathrm{N}$ & Mean Rank & Sum of Ranks \\
\hline \multirow[t]{4}{*}{ POSTEST - PRETEST } & Negative Ranks & $0^{\mathrm{a}}$ & .00 & .00 \\
\hline & Positive Ranks & $8^{b}$ & 4.50 & 36.00 \\
\hline & Ties & $0^{c}$ & & \\
\hline & Total & 8 & & \\
\hline
\end{tabular}

Table 9 Test Statistics ${ }^{\mathrm{b}}$

\begin{tabular}{|l|r|}
\hline & \multicolumn{1}{|c|}{$\begin{array}{c}\text { POSTEST - } \\
\text { PRETEST }\end{array}$} \\
\hline$Z$ & $-2.524^{\mathrm{a}}$ \\
Asymp. Sig. (2-tailed) & .012 \\
\hline a. Based on negative ranks. \\
b. Wilcoxon Signed Ranks Test
\end{tabular}

\subsubsection{Field Analysis Results}

Waste management model implemented in schools takes time to apply it to fruition. However, physical changes and management changes such as schools all schools have to have a separate trash, trash in the classroom and the sink. Learning composting make compost schools are able to produce to meet their own needs. This is seen from the school began to look green and garden work again. In the majority of respondents (First Middle School) began to activate his account back in BSM, whereas most of the other junk that segregated schools are given directly to the cleaners to be given to the local collectors. Malang Garbage Bank will pick up trash from the collectors. School cleaners sold at a price below BSM collectors. However this is rather encouraging school cleaners because of the additional revenue from their net trash. In SMP 15 junior high school students in which there are 1000, waste has been disaggregated and centralized certain diarea, but because there are many poor communities in the area, then clean the inorganic waste is given to people who will use it.

\subsection{Discussion of Waste Management Model for Junior High School 4.4.1 Waste Management Systems Model}

The waste management model has a participatory and sustainable principles. Participatory means that this activity requires mutual cooperation and collaboration between the teachers, students, and workers in the field. So that all the school community involved in the school waste management covering the entire process of planning, implementation and evaluation in accordance with the responsibilities and roles of each. Sustainability means that this activity should have a commitment to always be held constant so that the waste management activities requires a clear program, so it can be Included in school extracurricular acivities.

\subsubsection{Sub System Goal Setting}

The aim is the direction in which the activities and resources of the school directed. The aim is a detailed elaboration of the vision of the school. In the waste management activities is the goal of waste management activities (initial) can be selected as follows:

(a) Culture clean

(b) School adiwiyata

(c) Empowerment of people's economic

If the purpose of waste management is to instill a culture of learning that is clean, then clean environment will be reached, the school became comfortable, even if the school can obtain adiwiyata consistently perform its activities. Clean school is a school that is able to control their own garbage. Start inorganic waste (such as paper, plastic) and organic (leaves and twigs of trees, food scraps) to the waste water.

If the school is only intended as a school to receive the award adiwiyata, the school does have its environmental management activities with attention to the greening program. Garbage may only be a burden to the school because they have to be disposed of by another officer at an additional cost. Conscious waste not created because students realize that only the waste must be disposed of in place or composted.

If schools manage waste (pick and choose and there are officers), the waste may be sent to the bank and will get funds into the school's account. Schools can use these funds for the payment of electricity, water and Phone. If the compost wet waste is managed as it can be used to maintain the plants around the school, can 
be sold in the community when there are exhibitions in schools and compost can be sold to the city government in this case is DKP (Department of cleanliness and landscaping). So that economic empowerment is the outcome of destination choice of school is a school or school adiwiyata clean.

\subsubsection{Sub System Behavior Modifier \\ (1). Reinforcement}

Making a clean culture can be embedded either in the student then every effort is made to be shown the results. For example, cleaning up the trash can generate money that can be saved direkening grade students and can be used for classes, managing waste can produce useful goods or can be sold, manage organic waste can produce compost that can be sold or used alone. Attitude and diligent student who likes to work together should also be given the award. BF Skinner (Sule, et. al, 2014) put forward the theory of the formation of behavior (operant conditioning) or often referred to as behavior modification, positive reinforcement and conditioning skinnerian. This approach is based primarily on the effect of law (law of effect) which states that behavior followed by satisfying consequences tends to be repeated, whereas behavior followed by punishment consequences tend not to be repeated. Thus the behavior of someone in the future can be predicted or learned from experience in the past.

According to traditional reinforcement theory, only the responses given reinforcement (reinforcement) that will appear and the more powerful. Opinions Bandura not only reinforcement which is essential to bring the behavior, but also experience indirect impact on the appearance of a behavior. An example is a person who observes a consequence of the behavior. The person is then symbolically concluded that information and will use it if the situation is favorable to bring the behavior. So it can be concluded that the students learn to gather information through observation, both about the consequences of their own behavior and the behavior of other students. The information obtained is then applied in a variety of situations requiring such behavior. Behavior that gets reinforcement will be symbolized into memory so that information can help individuals determine a specific behavior in certain situations which result in certain consequences as well.

\section{(2).Modelling}

By getting a good model or sample continuously the student's behavior can be changed from the less good to be good, or from good to better. Can also change the behavior performed by inviting environment for students to observe, conduct research, experiments on the objects of study.

If the process of learning is done in the form of groups, each student will observe the behavior of the teachers and then the students will do it together or will reject it together. Therefore, teachers should always reflect the actions that highlight the cleanliness, neatness, discipline, care for the environment both when in class (in a teaching situation) and outside the classroom (such as the teacher's room clean and tidy, the teacher does not throw any rubbish and not let rubbish scattered). In addition, the study group will also result in observing the behavior of other students. Here, each child can see other students as modeling or learning object, for example about the accuracy, politeness, tolerance, communication skills, physical skills, the ability to appreciate other people, working together in groups, discipline. Expected with such direct observation is the positive behaviors of other students can be emulated by other students who will eventually be able to change their behavior towards more positive.

\section{(3) The Involment of Parents}

To involve parents in student activities is a form of communication in fostering student penyatuaan. If the parents are invited in the exhibition activities done in school environments, where the results of the exhibition is made from recycled, it will make the parents understand that the things that can make a student create on. If school taught how to live a clean and disciplined, then through a meeting between parents and the school will be shown a clean school environment as a result of cooperation between the school and students.

Parents should be informed about the correct disposal of waste (sorting and discarding appropriate place), so that understanding and awareness of the instilled at school is also reinforced by the behavior being taught at home. In this context also, the parents must provide proper waste separated at home as it is done in school. Parents must demonstrate to the students that they segregated garbage will be transported and increase revenue for the people who need it. Then the waste sorting activities will bring benefits to others In this case parents can be directed to the guidance of religion that requires people to do good without expecting anything in return. Meanwhile, parents can also ask for his daughter's son practicing how to compost at home to fulfill the needs of composting environment.

\subsubsection{Sub System Organizational}

Headmaster who has the most to the success of the role of waste management in schools. The school principal is the motor pengerak waste management activities at school. In the early stages of waste management 
activities, the headmaster should set aside a budget for the availability of school sanitation facilities adequate in number by the number of classes / students in the school, even anggran may have to set aside for the construction of storage bins. It takes a commitment from the principal for this waste management activities. The benefits of this new activity will be felt in a specified period, such as net culture, net includes income schools for the new school will be achieved.

The Headmaster may appoint a teacher to conduct preparatory activities / maintain adiwiyata. The teacher will be the coordinator for the teachers who assigned the other, which then will set the environmental ambassadors in their respective classes as an example.

Waste management activities require the creativity of the teachers. Therefore, schools should also establish cooperation with other parties such as the BSM ataupu environmentalists empowerment in order to always get innovation on waste management and its benefits. They can be incorporated as a consultant in the waste management activities of the school. Since 2013, the activities of environmental management and waste management in Indonesia is not included in the curriculum of national, but became a local curriculum (extracurricular). However, this should still be a challenge for schools to be able to cultivate cleanliness, waste conscious, concerned about the environment and social care as well as making an example that as a waste management activities of mutual aid to lift the people's economy. Coordinating teacher then make the assignment, schedule for environmental management activities and waste matter to form a cadre school including the school environment. Together with the teacher, a koordinataor create a schedule task that runs every week in extracurricular activities for students. These activities into the school culture. That attention to the environment and caring culture trash. Here examples of activities that can be scheduled by the school in terms of waste management and environmental management.

(1) Clean activities (Saturday cleaning)

(2) The creativity of recycling bins

(3) Weighing waste

(4) Exhibition recycled (on national days)

(5) Planting horticulture

(6) Labeling plants and plant fertilizer application

(7) Competition hygiene class

(8) Activities concerned about the environment (planting trees)

(9) The student movement in the ranks take waste

Environmental management activities and waste management are not included in the national curriculum anymore, but became a local curriculum (extracurricular). However, this should still be a challenge for schools to be able to cultivate cleanliness, waste conscious, concerned about the environment and social care as well as making examples of mutual aid activities to raise people's economy, especially for the younger generation.

\subsubsection{Sub System Physical Environment}

Sub physical system is the main thing that the net can be embedded culture. The existence of a good storage bins for organic waste and inorganic waste which will be submitted to the BSM is absolutely necessary. Because banks are not likely to take the garbage bins in small amounts, while the existing waste not to disturb the view of the school. There are 2 places that are needed for waste management, namely:

1. Place the dry waste (non organic waste)

2. Bins for compost (organic waste)

Dry place to store the waste paper and plastic to be submitted to the BSM. While the place is a trash compost from leaves and twigs are prepared to make compost. If there is water waste reprocessed want it to be important for the absorption well made. The lack of storage bins often make the party finally ended the waste management waste management activities. Besides the trash in front of the class and in the classroom are necessary in order garbage scattered. Labeling the trash needs to be done. Provision of waste management information from relevant parties to put pressure is meaningful to members of the school's waste management activities.

Some things to consider in net cultural investment are as follows: schools can prevent students from spending food produce wet waste by making the cafeteria without wet garbage. Cafeteria washing dishes without activity and discard the rest of the food or processed food. The canteen provides food that has been packed (wrapped in leaves or paper) so avoid wet rubbish school very much. 
To facilitate students to hygiene, it is important for schools to provide classes around the bins according to its kind. Pupils are asked to always dispose of waste according to its place. In this regard, the school is obligated to provide a sink for students within easy reach.

\section{Conclusion}

Urban waste which is constantly increasing in line with population growth would become dangerous problem if the handling is not done together. Governments, communities, schools, universities, industry and the private sector should encourage waste management. School as the younger generation does not escape the container above his duty to inculcate education aware of the garbage. If done properly, the waste management activities in schools will also bring benefits. Benefits for educational and economic benefits.

School waste management is an activity that can lead to a culture of cleanliness, care for the environment, caring nation and has a value of mutual cooperation empowers social economy. This is consistent with the character of education in the government decides. Waste management model developed from the activities that made the school managed to do it, then do some testing on schools that fail to perform waste management activities of the school. From the results of tests performed, indicating that the model has an effective value to be implemented. And this is also supported by the observation of the changes of the physical and behavior of citizens as well as an increase in revenue for schools, school cleaners, scavengers collect waste and increase revenue. Junior High School waste management model that created this is a system consisting of subsystems affect each other. It's sub-system approach goals, sub-system physical approach, sub system variables behavior, sub-systems organizational structure

\section{References}

[1]. Kementrian Lingkungan Hidup. Profil Bank Sampah Di Indonesia. 2012.

[2]. Biro Pusat Statistik, Jawa Timur dalam angka, Sensus Ekonomi (Kantor Pusat Statistik. Jakarta,2010)

[3]. Dinas Pendidikan Kota Malang, malangkota.siap.web.id. 2013

[4]. Kompas,11 Juni 2010. Masyarakat Manfaatkan Sampah

[5]. Prakarsa,Infrastruktur Dalam Angka. 10(11), 2013, 1-5

[6]. Radar Malang,Kota Malang Banjir Sampah Setiap Hari.2012.

[7]. Panduan Pelaksanaan Pendidikan Karakter, Pusat Kurikulum dan Perbukuan, 2011

[8]. Nazir.Moh.Metode penelitian(Ghalia Indonesia,2014)

[9]. Yaya. Uji coba Model ( Pusat penelitian dan inovasi pendidikan: Pendidikan Nasional: Jakarta, 2009)

[10]. Santoso, Sigit. Statistik Non Parametrik(Alex Media Komputindo: Jakarta, 2004)

[11]. Djaali. Psycologi Belajar(Bumi Aksara:Bandung, 2014)

[12]. Ahmadi,Abu . Psikologi Belajar( Rineka Cipta: Jakarta, 2004)

[13]. Sule.E.T,Saefullah, K. Pengantar Manajemen (Kencana Prenadamedia, 2012)

[14]. Bandura, A, Social Learning Theory( Englewood Cliffs, New Jersey: Prentice-Hall,1977

[15]. Kompas,11 Juni 2010. Masyarakat Manfaatkan Sampah

[16]. Dodie. Sekali lagi, Pendidikan Karakter. Media Indonesia, 3 Februari 2014

[17]. Yaya. Uji Coba Model. Pusat Penelitian dan Inovasi Pendidikan. Badan Penelitian dan Pengembangan. Pendidikan Nasional. Jakarta, 2009. 